Original

\title{
Fibroblast growth factor 2 regulates bone sialoprotein gene transcription in human breast cancer cells
}

\author{
Zhengyang $\mathrm{Li}^{1,3)}$, Zhitao Wang ${ }^{1,3)}$, Li Yang ${ }^{1,3)}$, Xinyue $\mathrm{Li}^{1,3)}$, Yoko Sasaki ${ }^{1)}$, \\ Shuang Wang ${ }^{1,4)}$, Shouta Araki ${ }^{1)}$, Masaru Mezawa'), Hideki Takai ${ }^{1,2)}$, \\ Youhei Nakayama ${ }^{1,2)}$ and Yorimasa Ogata ${ }^{1,2)}$ \\ ${ }^{1)}$ Department of Periodontology, Nihon University School of Dentistry at Matsudo, Chiba, Japan \\ ${ }^{2)}$ Research Institute of Oral Science, Nihon University School of Dentistry at Matsudo, Chiba, Japan \\ ${ }^{3)}$ Tianjin Stomatology Hospital, Tianjin, China \\ ${ }^{4)}$ Stomatology College of Tianjin Medical University, Tianjin, China
}

(Received 7 December 2009 and accepted 22 January 2010)

\begin{abstract}
Bone sialoprotein (BSP) is a major noncollagenous, extracellular matrix glycoprotein associated with mineralized tissues. Fibroblast growth factor 2 (FGF2) is recognized as a potent mitogen for a variety of mesenchymal cells. FGF2 produced by osteoblasts accumulates in the bone matrix and acts as an autocrine/paracrine regulator of osteoblasts. We previously reported that FGF2 regulates BSP gene transcription through the FGF2 response element (FRE) and activator protein 1 (AP1) binding site overlapping with the glucocorticoid response element in the rat BSP gene promoter. In the present study, FGF2 $(10 \mathrm{ng} / \mathrm{ml})$ increased BSP and Runx2 mRNA levels at $6 \mathrm{~h}$ in MCF7 human breast cancer cells. Transient transfection analyses were performed using chimeric constructs of the human BSP gene promoter linked to a luciferase reporter gene. Treatment of MCF7 cells with FGF2 $(10 \mathrm{ng} / \mathrm{ml})$ increased the luciferase activity of the constructs between -84LUC and -927LUC. Gel mobility shift analyses showed that FGF2 increased the binding of AP1 and CRE2. The CRE2- and AP1-protein complexes were disrupted by antibodies against CREB1, c-Fos, c-Jun, Fra2, p300 and Runx2. These studies demonstrate that FGF2 stimulates

Correspondence to Dr. Yorimasa Ogata, Department of Periodontology, Nihon University School of Dentistry at Matsudo, 2-870-1 Sakaecho-nishi, Matsudo, Chiba 271-8587, Japan Tel: +81-47-360-9362

Fax: +81-47-360-9362

E-mail: ogata.yorimasa@nihon-u.ac.jp
\end{abstract}

BSP transcription in MCF7 human breast cancer cells by targeting the AP1 and CRE2 elements in the human BSP gene promoter. (J Oral Sci, 125-132, 2010)

Keywords: bone sialoprotein; breast cancer; FGF2; transcription.

\section{Introduction}

Bone sialoprotein (BSP) is a highly sulfated, phosphorylated, and glycosylated protein that has been identified as a major component of the mineralized bone matrix $(1,2)$. Due to its highly negatively charged characteristics, BSP can sequester calcium ions via conserved polyglutamate regions, which have hydroxyapatite crystal nucleation potential (3). Through the RGD motif, BSP mediates the attachment and activation of osteoclasts (4) and can facilitate attachment of normal bone or cancer cells to mineralized tissue surfaces $(4,5)$. Through its binding to factor $\mathrm{H}$, BSP can protect cells from complement-mediated cell lysis, which may be important for cancer cell survival (6). The human BSP gene has been cloned and partially characterized (7-10). Its promoter has an inverted TATA box (nt -28 to -23) (7-10), an inverted CCAAT box (nt -54 to -50 ) which is required for basal transcription (9-11), and two cAMP response elements (CRE1; -79 to -72 and CRE2; -674 to -667) $(9,10,12)$. In addition, a fibroblast growth factor 2 (FGF2) response element (FRE; -96 to -89) $(9,10,13-15)$, three activator protein 1 (AP1) response elements (AP1(1); -148 to -142 , 
AP1(2); -483 to -477 and AP1(3); -797 to -791$)(9,10)$, and a homeodomain protein-binding site (HOX; -200 to -191) $(7,14)$ have been characterized.

FGF2 belongs to a large family of at least 23 related heparin-binding proteins, sharing 35-55\% sequence similarity (16-20). It stimulates the proliferation of all cells of mesodermal origin and many cells of neuroectodermal, ectodermal, and endodermal origin $(21,22)$. FGF2 induces neuron differentiation, survival and regeneration, and modulates embryonic development and differentiation (23). These functions of FGF2 observed in vitro suggest that, in vivo, FGF2 may play a role in the modulation of normal processes such as angiogenesis, wound healing, tissue repair, embryonic development, differentiation, neuronal function and neural degeneration (21-23). BSP is primarily expressed by mature osteoblasts, osteoclasts and hypertrophic chondrocytes $(24,25)$, and is also detectable in breast (26), prostate (27) and lung tumors (28), which can metastasize to bone, suggesting that BSP may play a role in the pathogenesis of bone metastases (26).

Previously, we have shown that FGF2 increases BSP gene transcription via the tyrosine and mitogen-activated protein (MAP) kinase pathways (15), and that the effect of FGF2 is mediated through FRE and AP1 binding site overlapping with the glucocorticoid response element in the rat BSP gene promoter $(15,29,30)$. In the present study, to determine the molecular mechanism of FGF2 regulation of the BSP gene, we analyzed the effects of FGF2 on the expression of BSP in MCF7 human breast cancer cells.

\section{Materials}

\section{Materials and Methods}

Alpha minimum essential medium ( $\alpha$-MEM), fetal calf serum (FCS), lipofectamine, penicillin, streptomycin and trypsin-EDTA were obtained from Invitrogen (Carlsbad, CA). pGL3-basic and pSV $\beta$-galactosidase ( $\beta$-Gal control) vectors were purchased from Promega Co. (Madison, WI, USA). An EXScript RT reagent kit and SYBR Premix Ex Taq were purchased from Takara-bio (Tokyo, Japan). MCF7 was obtained from the American Type Culture Collection. All chemicals used were of analytical grade.

\section{Cell culture}

MCF7 human breast cancer cells were used in these studies. Cells were first grown to confluence in $60-\mathrm{mm}$ tissue culture dishes in $\alpha$-MEM medium containing $10 \%$ FCS, then cultured in $\alpha$-MEM without serum, and incubated with FGF2 $(10 \mathrm{ng} / \mathrm{ml})$ for between 3 and $24 \mathrm{~h}$. Nuclear proteins were extracted by addition of extra proteinase inhibitors (the extraction buffer was $0.42 \mathrm{M}$ $\mathrm{NaCl}, 1.5 \mathrm{mM} \mathrm{MaCl}_{2}, 0.2 \mathrm{mM}$ EDTA, $1 \mathrm{mM}$ dithiothreitol
(DTT), 25\% (v/v) glycerol, $0.5 \mathrm{mM}$ phenylmethyl-sulfonyl fluoride, $2 \mu \mathrm{g} / \mathrm{ml}$ leupeptin, $2 \mu \mathrm{g} / \mathrm{ml}$ pepstatin A, $1 \mu \mathrm{g} / \mathrm{ml}$ aprotinin, $\mathrm{pH}$ 7.9) (15).

\section{Real-time PCR}

MCF7 cells were incubated with FGF2 $(10 \mathrm{ng} / \mathrm{ml})$ for 3-24 h, then the total RNA was extracted with guanidinium thiocyanate and purified. Total RNA $(1 \mu \mathrm{g})$ was used as a template for cDNA synthesis. cDNA was prepared using the EXScript RT reagent kit. Quantitative real-time PCR was performed using the following primer sets: BSP forward, 5'-CTGGCACAGGGTATACAGGGTTAG-3'; BSP reverse, 5'-ACTGGTGCCGTTTATGCCTTG-3'; Runx2 forward, 5'-ATGTGTGTTTGTTTCAGCAGCA-3'; Runx2 reverse, 5'-TCCCTAAAGTCACTCGGTATGTGTA-3'; GAPDH forward, 5'-GCACCGTCAAGGCTGAGAAC3'; GAPDH reverse, 5'-ATGGTGGTGAAGACGCCAGT3; using the SYBR Premix Ex Taq in a TP800 thermal cycler dice real time system (Takara-bio, Tokyo, Japan). The amplification reactions were performed in a final volume of $25 \mu \mathrm{l}$ containing $2 \times$ SYBR Premix EX Taq (12.5 $\mu \mathrm{l}), 0.2 \mu \mathrm{M}$ forward and reverse primers $(0.5 \mu \mathrm{l})$ and 100 ng cDNA $(10 \mu \mathrm{l})$. To reduce variability between replicates, PCR premixes, which contained all reagents except for cDNA, were prepared and aliquoted into $0.2 \mathrm{ml} \mathrm{Hi-8-}$ tubes (Takara, Tokyo, Japan). The thermal cycling conditions were $10 \mathrm{~s}$ at $95^{\circ} \mathrm{C}$ and 40 cycles of $5 \mathrm{~s}$ at $95^{\circ} \mathrm{C}$ and $30 \mathrm{~s}$ at $60^{\circ} \mathrm{C}$. Post-PCR melting curves confirmed the specificity of single-target amplification, and the expressions of BSP and Runx2 relative to GAPDH were determined in quadruplicate.

\section{Transient transfection assays}

Exponentially growing MCF7 cells were used for transfection assays. Twenty-four hours after plating, cells at $50-60 \%$ confluence were transfected using lipofectamine reagent. The transfection mixture included $1 \mu \mathrm{g}$ of a luciferase (LUC) construct (31) and $2 \mu \mathrm{g}$ of the $\beta$-Gal vector as an internal control. Two days after transfection, the cells were deprived of serum for $12 \mathrm{~h}$, and $10 \mathrm{ng} / \mathrm{ml} \mathrm{FGF2}$ were added for $6 \mathrm{~h}$ prior to harvest. The luciferase assay was performed in accordance with the supplier's protocol (PicaGene; Toyo Inki, Tokyo, Japan) using a luminescence reader (Acuu FLEX Lumi 400; Aloka, Tokyo, Japan) to measure the luciferase activity.

\section{Gel mobility shift assays}

Confluent MCF7 cells in T-75 flasks incubated for 3$24 \mathrm{~h}$ with FGF2 (10 ng/ml) in $\alpha$-MEM without serum were used to prepare the nuclear extracts. Double-stranded oligonucleotides encompassing the inverted CCAAT, 
CRE1, CRE2, FRE, HOX and AP1(1) sequences in the human BSP promoter were prepared. For gel shift analysis, the double-stranded oligonucleotides were end-labeled with $\left[\gamma^{3}{ }^{32} \mathrm{P}\right]$ ATP and T4 polynucleotide kinase. Nuclear protein extracts $(3 \mu \mathrm{g})$ were incubated for $20 \mathrm{~min}$ at room temperature with $0.1 \mathrm{pM}$ radiolabeled double-stranded oligonucleotide. Following incubation, the protein-DNA complexes were resolved by electrophoresis on $5 \%$ nondenaturing acrylamide gels (38:2 acrylamide/bis acrylamide) run at $200 \mathrm{~V}$ at RT. After electrophoresis, the gels were dried and autoradiograms were prepared and analyzed using an image analyzer. Double-stranded oligonucleotide sequences were: CCAAT (nts, -64 to -41 , 5'-CGTGACAGTGATTGGCTGTTGGAA-3'), CRE1 (nts, -89 to -63, 5'-ATCCACGTTCTGACATCACCTT GGTCG), CRE2 (nts, -680 to -658, 5'-ATCAGCTGA CCTCACATGCACGA-3'), AP1(1) (nts, -158 to -129, 5' CGTTTCTTGTTTATTCAACTGAGCCTGTGT-3'), FRE (nts, -102 to -83, 5'-TTTTCTGGTGAGAATCC ACGA-3'), HOX (nts, -208 to -180, 5' -CTAAACCT TCAATTAAATTCCACAATGCA-3').

\section{Statistical analysis}

Quadruplicate samples were analyzed for each experiment, and experiments were replicated to ensure consistency of the responses to drugs. Significance of differences between control and treatment runs were determined using unpaired Student's $t$ test.

\section{Results}

FGF2 increases BSP and Runx2 expression in MCF7 cells

MCF7 cells were treated with FGF2, and changes in the levels of BSP and Runx 2 mRNAs were analyzed by realtime PCR. It was found that FGF2 $(10 \mathrm{ng} / \mathrm{ml})$ increased the levels of BSP and Runx2 mRNAs at 6 and $12 \mathrm{~h}$ (Fig. $1)$.

\section{FGF2 stimulates BSP transcription in MCF7 cells}

To determine the site of FGF2-regulated transcription in the 5'-flanking region of the human BSP gene, -43 to +60 (-43LUC), -60 to +60 (-60LUC), -84 to +60 (-84LUC), -108 to +60 (-108LUC), -116 to +60 (-116LUC), -184 to +60 (-184LUC), -311 to +60 (-311LUC), -428 to +60 (428LUC) and -927 to +60 (-927LUC) human BSP gene promoters ligated to the luciferase reporter gene were transiently transfected into MCF7 cells, and the transcriptional activities were determined in the presence or absence of FGF2. FGF2 (10 ng/ml, $6 \mathrm{~h})$ increased the luciferase activity of the constructs from -84LUC to -
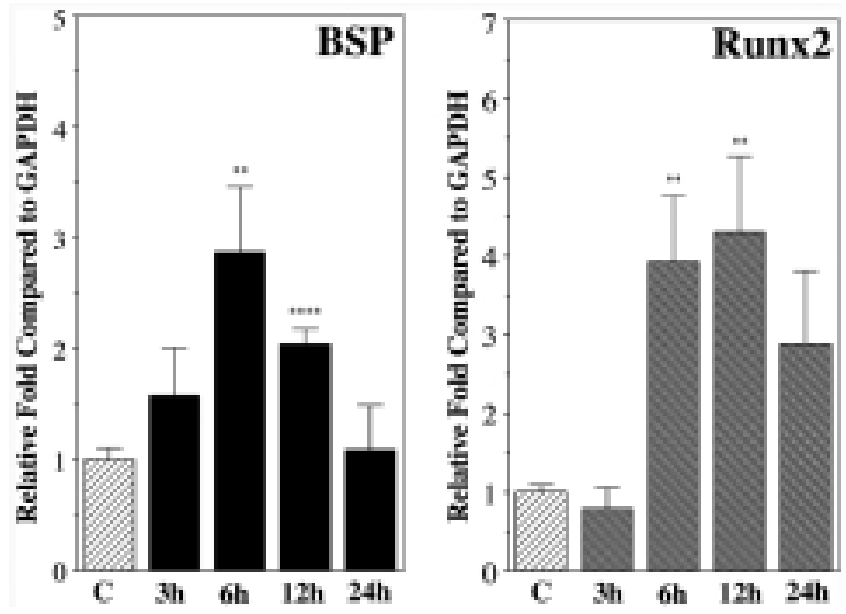

Fig. 1 Effects of FGF2 on levels of BSP and Runx2 mRNA in MCF7 cells. MCF7 cells were treated with or without FGF2 (10 ng/ml) for 3, 6, 12, and $24 \mathrm{~h}$. Then, total RNA was extracted, and the expressions of BSP, Runx2 and GAPDH mRNA in the MCF7 cells were measured by real-time PCR. The amounts of mRNA for BSP and Runx2 relative to GAPDH were calculated. The experiments were performed in quadruplicate for each data point. Quantitative analyses of the quadruplicate data sets are shown with standard errors. Significant differences from control: ** $(P<0.05) ; * * * *(P<0.01)$.

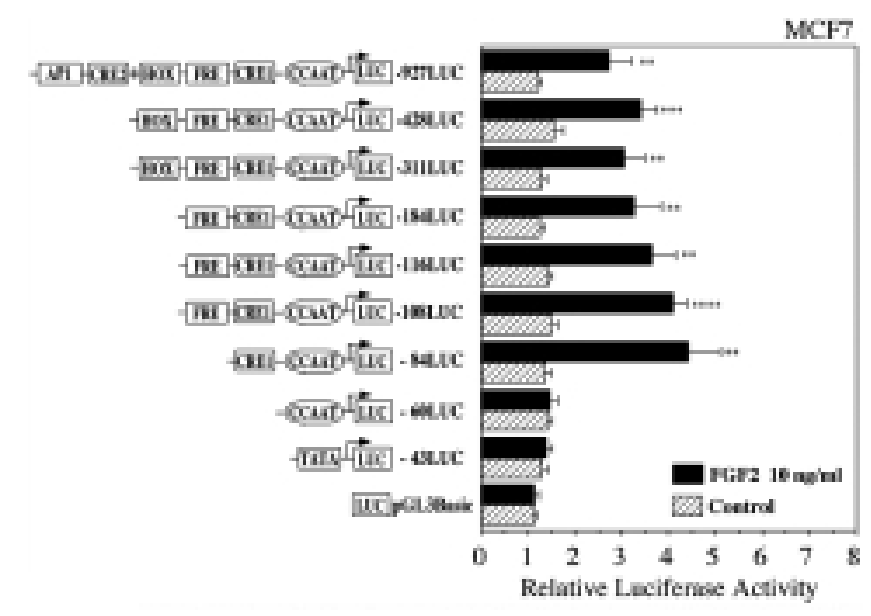

Fig. 2 FGF2 up-regulates human BSP promoter activity in MCF7 cells. Transient transfections of MCF7 cells in the presence or absence of FGF2 (10 ng.ml) for $6 \mathrm{~h}$ were used to determine transcriptional activities of chimeric constructs that included various-sized human BSP promoters ligated to a luciferase reporter gene. The data for transcriptional activities obtained from quadruplicate transfections with constructs, pGL3basic and -43LUC to -927LUC, have been combined, and the values are expressed with standard errors. Significant differences from control: $* *(P<0.05)$; $* * *(P<0.02) ; * * * *(P<0.01)$. 


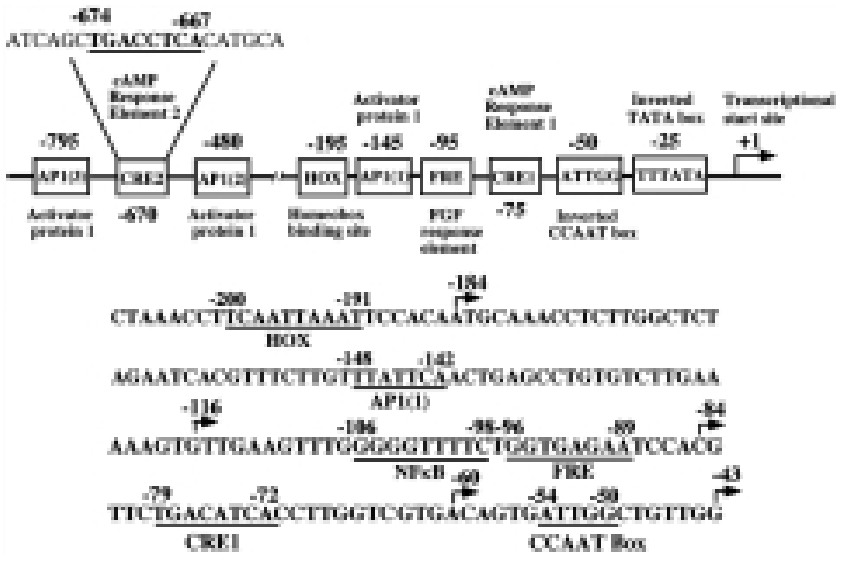

Fig. 3 Regulatory elements in the human BSP promoter. Upper panel; The positions of the inverted TATA and CCAAT boxes, cAMP response element 1 (CRE1), homeobox-binding site (HOX), cAMP response element 2 (CRE2), activator protein 1 (AP1), shear stress response element (SSRE1), activator protein 2 (AP2) and SSRE2 are shown in the human BSP gene promoter. The nucleotides are numbered relative to the transcription start sites (+1). CRE2 (nts -674 to -667), AP1(3) (nts -794 to -800), SSRE1 (nts -893 to -888 ), AP2 (nts -1148 to -1139 ) and SSRE2 (nts -2474 to 2469) are present. Lower panel: The nucleotide sequences of the proximal promoter region of the human BSP gene are shown from nucleotides -43 to 201.

927LUC (Fig. 2). Within the DNA sequence unique to the -84LUC to -927LUC region is an inverted CCAAT box (ATTGG; between -54 and -50), a CRE1 (-79 to -72), a FRE (-96 to -89), an AP1(1) (-148 to -142), a HOX (-200 to -191 ) and a CRE2 (-674 to -667) (Fig. 3).

\section{Gel mobility shift assays}

To identify which nuclear proteins can bind to the promoter region (-84LUC to -927LUC), double-stranded oligonucleotides of inverted CCAAT, CRE1, FRE, AP1(1), HOX and CRE2 elements were end-labeled and incubated with equal amounts $(3 \mu \mathrm{g})$ of nuclear proteins extracted from confluent MCF7 cells that were either not treated (control) or treated with FGF2 (10 ng/ml) for 3, 6 and 12 $\mathrm{h}$. When we used the inverted CCAAT sequence as a probe, the CCAAT-NFY protein complex did not change after FGF2 stimulation (Fig. 4). With nuclear extracts from confluent control cultures of MCF7 cells, shifts of AP1(1)- and CRE2-protein complexes were evident (Fig. 4; lanes 5 and 9). After FGF2 (10 ng/ml) stimulation, the AP1(1)-protein complex was increased at $3 \mathrm{~h}$ (Fig. 4; lane

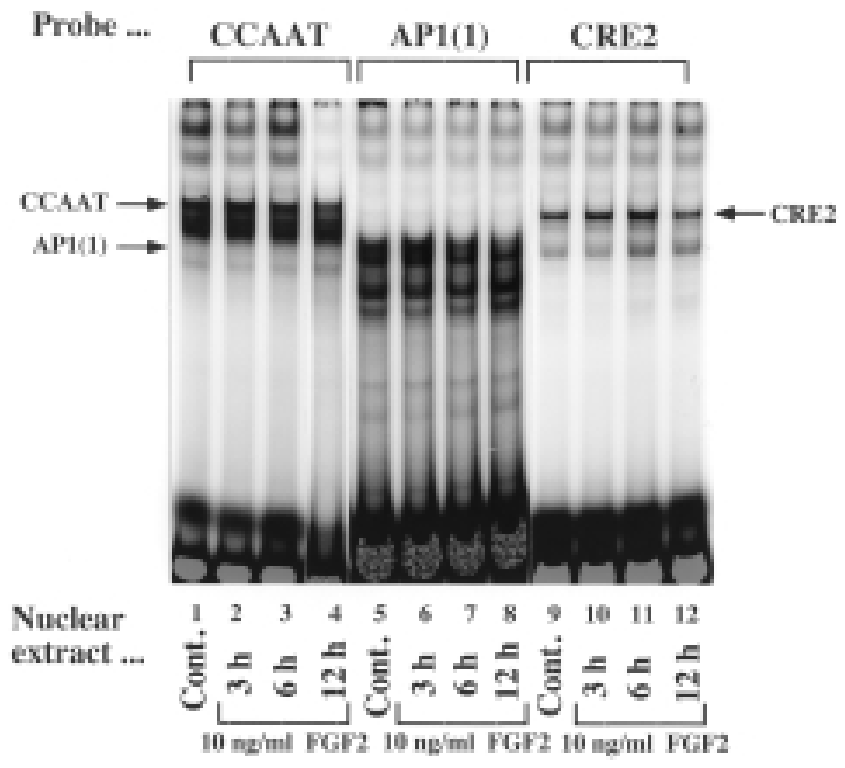

Fig. 4 FGF2 up-regulates nuclear proteins that recognize AP1(1) and CRE2. Radiolabeled double-stranded CCAAT (-64 CGTGACAGTGATTGGCTGTTGG AA -41), AP1(1) (-158 CGTTTCTTGTTTATTCA ACTGAGCCTGTGT -129), CRE2 (-680 ATCAGC TGACCTCACATGCACGA -658) oligonucleotides were incubated with nuclear protein extracts $(3 \mu \mathrm{g})$ obtained from MCF7 cells stimulated without (lanes 1, 5 and 9) or with FGF2 (10 ng/ml) for $3 \mathrm{~h}$ (lanes 2, 6 and 10), $6 \mathrm{~h}$ (lanes 3, 7 and 11), and $12 \mathrm{~h}$ (lanes 4, 8 and 12). DNA-protein complexes were separated on $5 \%$ polyacrylamide gel in low-ionic-strength Trisborate buffer, dried under vacuum, and exposed to an imaging plate for quantitation using an image analyzer.

6) and the CRE2- protein complex was increased at $6 \mathrm{~h}$ (Fig. 4; lane 11). FGF2 did not induce CRE1-, FRE- or HOX-protein complex formation (data not shown). The specific interactions of the CRE2- and AP1(1)-protein complexes were demonstrated by competition experiments in which a 40-fold molar excess CRE2 and AP1(1) reduced the formation of the DNA-protein complexes. In contrast, mAP1(1), CRE1 and CRE2 did not compete during AP1(1)-protein complex formation, and mCRE2, CRE1 and AP1(1) did not compete during CRE2-protein complex formation (Fig. 5). To further characterize the proteins in the complexes formed with CRE2 and AP1(1), we used antibodies against several transcription factors. CRE2protein complexes were disrupted by antibodies against CREB1, c-Fos, c-Jun, Fra2, P300, Runx2, Dlx5 and Smad1 (Fig. 6), whereas AP1(1)-protein complexes were disrupted by antibodies against CREB1, c-Fos, c-Jun, JunD and p300 (Fig. 7). 


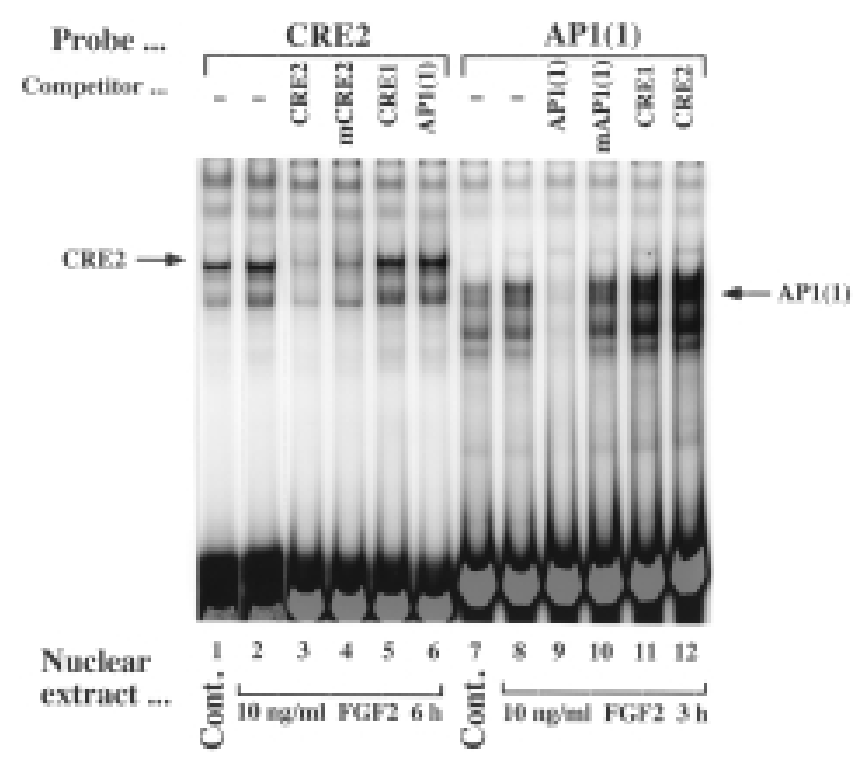

Fig. 5 Specific binding of nuclear proteins to the CRE2 and AP1(1). Competition reactions were performed using a 40-fold molar excess of unlabeled CRE2 (-680 ATCAGCTGACCTCACATGCACGA -658) (lanes 3 and 12), mutation-CRE2 (mCRE2; -680 ATCAGCTGACCgaACATGCACGA -658) (lane 4), CRE1 (-89 ATCCACGTTCTGACATCACCTTG GTCG -63) (lanes 5 and 11), AP1(1) (-158 CGT TTCTTGTTTATTCAACTGAGCCTGTGT -129), (lanes 6 and 9), and mutation-AP1(1) (mAP1(1); -158 CGTTTCTTGTTTATgaAACTGAGCCTGTGT 129) (lane 10) oligonucleotides. DNA-protein complexes were separated on $5 \%$ polyacrylamide gel and exposed to an imaging plate for quantitation using an image analyzer.

\section{Discussion}

FGFs have a prominent role in bone development and growth. BSP has been characterized as a unique marker of osteogenic differentiation that can regulate the formation of mineral crystals $(1,2)$. In this study, we identified the CRE2 and AP1(1) elements in the human BSP gene promoter that mediates FGF2-stimulated BSP transcription in MCF7 human breast cancer cells.

Previously, we had reported that FGF2 increased the expression of BSP in osteosarcoma-derived ROS17/2.8 osteoblast-like cells. The relationship between BSP and FGF2 may be relevant to the expression of BSP in tumors. In addition to production by osteogenic tumors, BSP is also expressed in breast, lung, thyroid and prostate cancers (26-28,32,33). The expression of BSP in human primary breast cancers has been associated with an increased risk

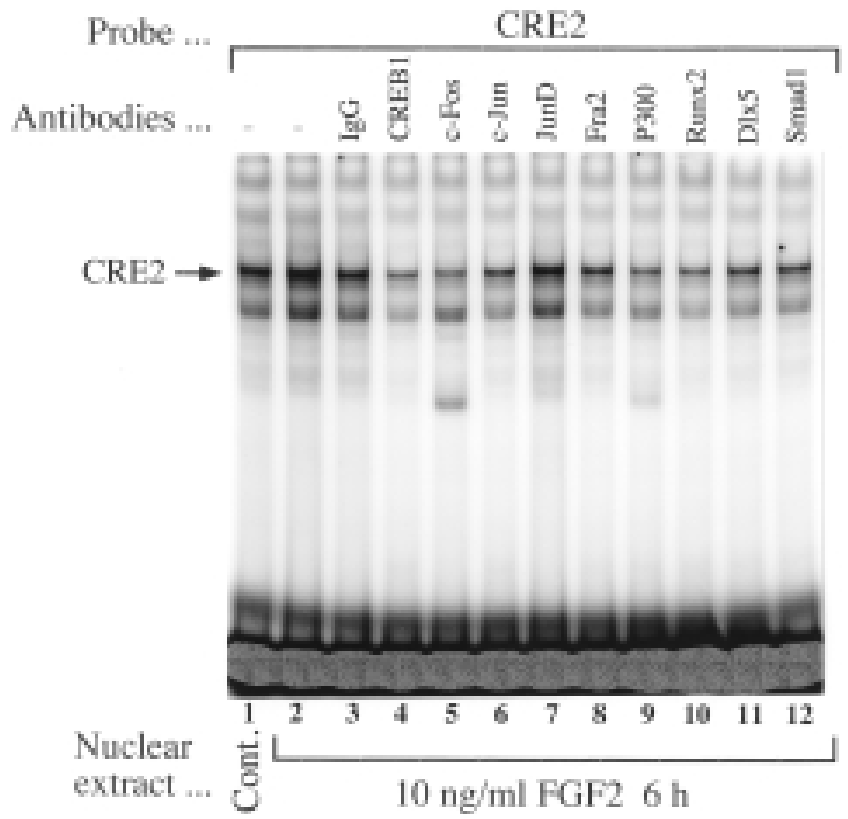

Fig. 6 Specific binding of nuclear proteins to CRE2. Radiolabeled double-stranded CRE2 was incubated with nuclear protein extracts $(3 \mu \mathrm{g})$ obtained from MCF7 cells stimulated without or with FGF2 (10 $\mathrm{ng} / \mathrm{ml}$ ) for $6 \mathrm{~h}$. Supershift experiments were performed with $0.4 \mu \mathrm{g}$ of antibodies added separately to each gel shift reaction.

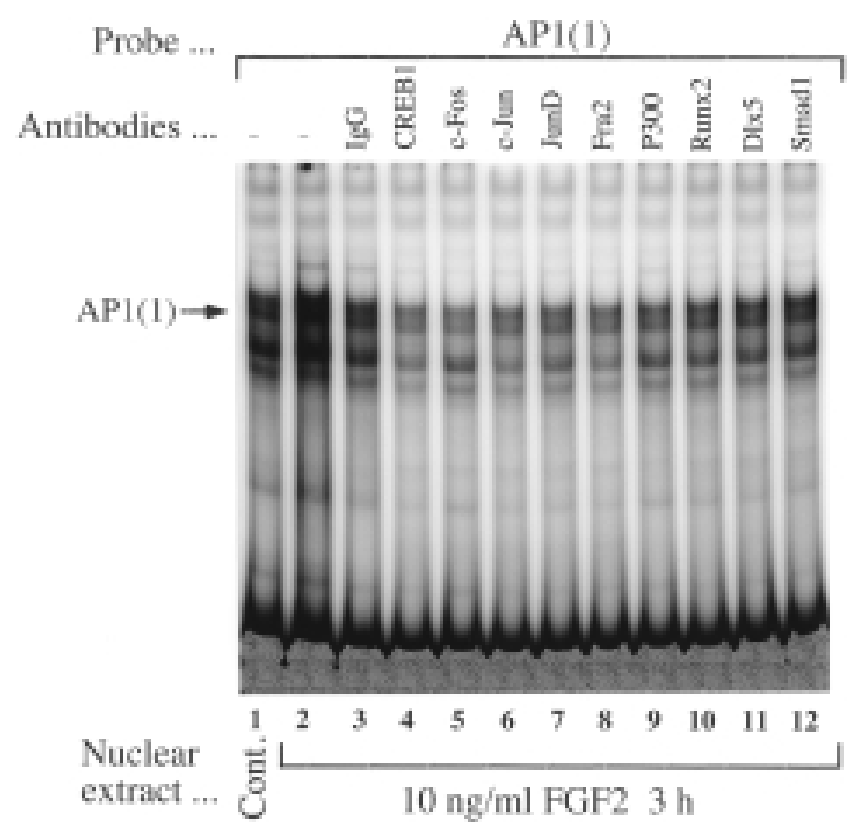

Fig. 7 Specific binding of nuclear proteins to AP1(1). Radiolabeled double-stranded AP1(1) was incubated with nuclear protein extracts $(3 \mu \mathrm{g})$ obtained from MCF7 cells stimulated without or with FGF2 (10 $\mathrm{ng} / \mathrm{ml}$ ) for $3 \mathrm{~h}$. Supershift experiments were performed with $0.4 \mu \mathrm{g}$ of antibodies added separately to each gel shift reaction. 
of subsequent bone metastases and a poor survival rate $(26,32)$. The ability of BSP to bind to hydroxyapatite and to mediate cell attachment through cell-surface integrins may be involved in the osteotropism of the metastatic cells $(1,2,26)$. Various tumor cell lines express FGF2 (3436 ), and FGF2 is significantly increased in prostate cancers in comparison with normal prostate (36). Also, the concentrations of FGF2 in nipple fluid are significantly increased in breast cancer patients (37). Human breast cancer cell lines and breast tumor samples express the FGF and FGF receptor genes, suggesting a possible relationship between expression of FGF2 and that of BSP in osteotropic cancers (38).

Real-time PCR demonstrated that FGF2 increased the expression of BSP and Runx2 mRNAs in MCF7 cells (Fig. 1). Runx2 plays an essential role in osteoblast differentiation, and Runx2-deficient mice display absence of bone due to osteoblast differentiation arrest (39). Transient transfection assays showed that BSP promoter activities (-84LUC - 927LUC) were increased by FGF2 (Fig. 2). The involvement of the CRE2 and AP1(1) elements was further supported by gel shift assays in which proteins from nuclear extracts forming complexes with CRE2 and AP1(1) were increased by FGF2 (Fig. 4). While FRE is the main target of FGF2 signaling in rat osteoblast-like cells $(14,15,30,40)$, FGF2 did not induce FRE-protein complex formation in MCF7 cells. We previously reported Runx2, Dlx5 and Smad1 were FRE binding transcription factors in osteoblastic Saos 2 cells (14). The results of supershift assays showed that CRE2 interacted with CREB1, c-Fos, c-Jun, Fra2, P300, Runx2, Dlx5 and Smad1, and that AP1(1) interacted with CREB1, c-Fos, c-Jun, JunD and p300 in MCF7 cells. The CREB1 and AP1 transcription factors JunD and Fra2 regulate BSP gene expression in human breast cancer cells (13). P300 may play an architectural role at the osteocalcin gene promoter by interacting with Runx2 and the vitamin D3 receptor, and by connecting factors bound to the distal and proximal sites of the promoter (41). In normal osteoblasts, FRE is the main target of FGF2 regulation of BSP transcription, whereas regulation of BSP transcription in MCF7 human breast cancer cells is under the control of transcription factors and transcriptional coactivators that bind to the distal CRE2 and proximal AP1(1) elements. In conclusion, our present findings indicate that FGF2 induces expression of the BSP gene in human breast cancer cells via the CRE2 and AP1(1) elements in the gene promoter. Further study will be necessary to clarify why FRE-binding transcription factors (Runx2, Dlx5 and Smad1) and P300 are able to interact with CRE2 and how BSP transcription is induced in breast cancer cells.

\section{Acknowledgments}

This work was supported in part by a Grant for Supporting Projects for Strategic Research in Private Universities by the Ministry of Education, Culture, Sports, Science, and Technology (MEXT), 2008-2012, and a Nihon University Multidisciplinary Research Grant for 2009-2010.

\section{References}

1. Ogata Y (2008) Bone sialoprotein and its transcriptional regulatory mechanism. J Periodontal Res 43, 127-135.

2. Ganss B, Kim RH, Sodek J (1999) Bone sialoprotein. Crit Rev Oral Biol Med 10, 79-98.

3. Hunter GK, Goldberg HA (1993) Nucleation of hydroxyapatite by bone sialoprotein. Proc Natl Acad Sci USA 90, 8562-8565.

4. Mintz KP, Grzesik WJ, Midura RJ, Robey PG, Termine JD, Fisher, LW (1993) Purification and fragmentation of nondenatured bone sialoprotein: evidence for a cryptic, RGD-resistant cell attachment domain. J Bone Miner Res 8, 985-995.

5. Zhang JH, Tang J, Wang J, Ma W, Zheng W, Yoneda T, Chen J (2003) Over-expression of bone sialoprotein enhances bone metastasis of human breast cancer cells in a mouse model. Int J Oncol 23, 1043-1048.

6. Fedarko NS, Fohr B, Robey PG, Young MF, Fisher LW (2000) Factor H binding to bone sialoprotein and osteopontin enables tumor cell evasion of complement-mediated attack. J Biol Chem 275, 16666-16672.

7. Kim RH, Shapiro HS, Li JJ, Wrana JL, Sodek J (1994) Characterization of the human bone sialoprotein (BSP) gene and its promoter sequence. Matrix Biol 14, 31-40.

8. Kiyoshima T, Yamauchi M, Wong C, Jheon A, Ganss B, Sodek J (2002) An L1 element disrupts human bone sialoprotein promoter: lack of tissuespecific regulation by distalless 5 (Dlx5) and runt homeodomain protein2 (Runx2)/core binding factor a1 (Cbfa1) elements. Gene 299, 205-217.

9. Araki S, Mezawa M, Sasaki Y, Yang L, Li Z, Takai H, Nakayama Y, Ogata Y (2009) Parathyroid hormone regulation of the human bone sialoprotein gene transcription is mediated through two cAMP response elements. J Cell Biochem 106, 618-625.

10. Mezawa M, Araki S, Takai H, Sasaki Y, Wang S, Li X, Kim D, Nakayama Y, Ogata Y (2009) Regulation of human bone sialoprotein gene transcription by platelet-derived growth factor-BB. 
Gene 435, 80-87.

11. Kim RH, Sodek J (1999) Transcription of the bone sialoprotein gene is stimulated by $\mathrm{v}$-Src acting through an inverted CCAAT box. Cancer Res 59, 565-571.

12. Huang WC, Xie Z, Konaka H, Sodek J, Zhau HE, Chung LW (2005) Human osteocalcin and bone sialoprotein mediating osteomimicry of prostate cancer cells: role of cAMP-dependent protein kinase A signaling pathway. Cancer Res 65, 2303-2313.

13. Detry C, Lamour V, Castronovo V, Bellahcène A (2008) CREB-1 and AP-1 transcription factors JunD and Fra-2 regulate bone sialoprotein gene expression in human breast cancer cells. Bone 42, 422-431.

14. Nakayama Y, Nakajima Y, Kato N, Takai H, Kim DS, Arai M, Mezawa M, Araki S, Sodek J, Ogata Y (2006) Insulin-like growth factor-I increases bone sialoprotein (BSP) expression through fibroblast growth factor-2 response element and homeodomain protein-binding site in the proximal promoter of the BSP gene. J Cell Physiol 208, 326-335.

15. Shimizu-Sasaki E, Yamazaki M, Furuyama S, Sugiya H, Sodek J, Ogata Y (2001) Identification of a novel response element in the rat bone sialoprotein (BSP) gene promoter that mediates constitutive and fibroblast growth factor 2-induced expression of BSP. J Biol Chem 276, 5459-5466.

16. Coffin JD, Florkiewicz RZ, Neumann J, MortHopkins T, Dorn GW 2nd, Lightfoot P, German R, Howles PN, Kier A, O'Toole BA (1995) Abnormal bone growth and selective translational regulation in basic fibroblast growth factor (FGF-2) transgenic mice. Mol Biol Cell 6, 1861-1873.

17. Powers CJ, McLeskey SW, Wellstein A (2000) Fibroblast growth factors, their receptors and signaling. Endocr Relat Cancer 7, 165-197.

18. Nishimura T, Nakatake Y, Konishi M, Itoh N (2000) Identification of a novel FGF, FGF-21, preferentially expressed in the liver. Biochim Biophys Acta 1492, 203-206.

19. Yamashita T, Yoshioka M, Itoh N (2000) Identification of a novel fibroblast growth factor, FGF-23, preferentially expressed in the ventrolateral thalamic nucleus of the brain. Biochem Biophys Res Commun 277, 494-498.

20. Nakatake Y, Hoshikawa M, Asaki T, Kassai Y, Itoh N (2001) Identification of a novel fibroblast growth factor, FGF-22, preferentially expressed in the inner root sheath of the hair follicle. Biochim Biophys Acta 1517, 460-463.

21. Gospodarowicz D, Neufeld G, Schweigerer L (1986)
Molecular and biological characterization of fibroblast growth factor, an angiogenic factor which also controls the proliferation and differentiation of mesoderm and neuroectoderm derived cells. Cell Differ 19, 1-17.

22. Gospodarowicz D, Mescher AL, Brown KD, Birdwell CR (1977) The role of fibroblast growth factor and epidermal growth factor in the proliferative response of the corneal and lens epithelium. Exp Eye Res 25, 631-649.

23. Tcheng M, Oliver L, Courtois Y, Jeanny JC (1994) Effects of exogenous FGFs on growth, differentiation, and survival of chick neural retina cells. Exp Cell Res 212, 30-35.

24. Fisher LW, Whitson SW, Avioli LV, Termine JD (1983) Matrix sialoprotein of developing bone. J Biol Chem 258, 12723-12727.

25. Bianco P, Fisher LW, Young MF, Termine JD, Robey PG (1991) Expression of bone sialoprotein (BSP) in developing human tissues. Calcif Tissue Int 49, 421-426.

26. Waltregny D, Bellahcène A, de Leval X, Florkin B, Weidle U, Castronovo, V (2000) Increased expression of bone sialoprotein in bone metastases compared with visceral metastases in human breast and prostate cancers. J Bone Miner Res 15, 834-843.

27. Waltregny D, Bellahcène A, Van Riet I, Fisher LW, Young M, Fernandez P, Dewe W, de Leval J, Castronovo V (1998) Prognostic value of bone sialoprotein expression in clinically localized human prostate cancer. J Natl Cancer Inst 90, 1000-1008.

28. Bellahcène A, Maloujahmoum N, Fisher LW, Pastorino H, Tagliabue E, Menard S, Castronovo V (1997) Expression of bone sialoprotein in human lung cancer. Calcif Tissue Int 61, 183-188.

29. Yamauchi M, Ogata Y, Kim RH, Li JJ, Freedman LP, Sodek J (1996) AP-1 regulation of the rat bone sialoprotein gene transcription is mediated through a TPA response element within a glucocorticoid response unit in the gene promoter. Matrix Biol 15, 119-130.

30. Takai H, Araki S, Mezawa M, Kim DS, Li X, Yang L, Li Z, Wang Z, Nakayama Y, Ogata Y (2008) AP1 binding site is another target of FGF2 regulation of bone sialoprotein gene transcription. Gene 410, 97 104.

31. Ogata Y, Yamauchi M, Kim RH, Li JJ, Freedman LP, Sodek J (1995) Glucocorticoid regulation of bone sialoprotein (BSP) gene expression. Identification of a glucocorticoid response element in the bone sialoprotein gene promoter. Eur J 
Biochem 230, 183-192.

32. Bellahcène A, Menard S, Bufalino R, Moreau L, Castronovo V (1996) Expression of bone sialoprotein in primary human breast cancer is associated with poor survival. Int J Cancer 69, 350-353.

33. Bellahcène A, Albert V, Pollina L, Basolo F, Fisher LW, Castronovo V (1998) Ectopic expression of bone sialoprotein in human thyroid cancer. Thyroid 8,637 641.

34. Presta M, Moscatelli D, Joseph-Silverstein J, Rifkin DB (1986) Purification from a human hepatoma cell line of a basic fibroblast growth factor-like molecule that stimulates capillary endothelial cell plasminogen activator production, DNA synthesis, and migration. Mol Cell Biol 6, 4060-4066.

35. Moscatelli D, Presta M, Joseph-Silverstein J, Rifkin DB (1986) Both normal and tumor cells produce basic fibroblast growth factor. J Cell Physiol 129, 273-276.

36. Giri D, Ropiquet F, Ittmann M (1999) Alterations in expression of basic fibroblast growth factor (FGF) 2 and its receptor FGFR-1 in human prostate cancer. Clin Cancer Res 5, 1063-1071.

37. Liu Y, Wang JL, Chang H, Barsky SH, Nguyen M (2000) Breast-cancer diagnosis with nipple fluid bFGF. Lancet 356, 567.
38. Penault-Llorca F, Bertucci F, Adelaide J, Parc P, Coulier F, Jacquemier J, Birnbaum D, deLapeyriere O (1995) Expression of FGF and FGF receptor genes in human breast cancer. Int J Cancer 61, 170176.

39. Komori T, Yagi H, Nomura S, Yamaguchi A, Sasaki K, Deguchi K, Shimizu Y, Bronson RT, Gao YH, Inada M, Sato M, Okamoto R, Kitamura Y, Yoshiki S, Kishimoto T (1997) Targeted disruption of Cbfa1 results in a complete lack of bone formation owing to maturational arrest of osteoblasts. Cell 89, 755764.

40. Shimizu E, Nakayama Y, Nakajima Y, Kato N, Takai H, Kim DS, Arai M, Saito R, Sodek J, Ogata Y (2006) Fibroblast growth factor 2 and cyclic AMP synergistically regulate bone sialoprotein gene expression. Bone 39, 42-52.

41. Sierra J, Villagra A, Paredes R, Cruzat F, Gutierrez S, Javed A, Arriagada G, Olate J, Imschenetzky M, van Wijnen AJ, Lian JB, Stein GS, Stein JL, Montecino M (2003) Regulation of the bone-specific osteocalcin gene by p300 requires Runx $2 / \mathrm{Cbfa} 1$ and the vitamin D3 receptor but not p300 intrinsic histone acetyltransferase activity. Mol Cell Biol 23, 3339-3351. 